VASHINGTON

PHHATELIC SOCIETY

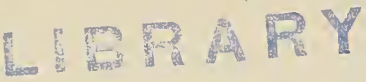

SY PURCHASE

BY EXCHANGE

BY GIFT

DATE Unknown.

CLASS 




\section{The Stamp Publications of the State of Colorado}




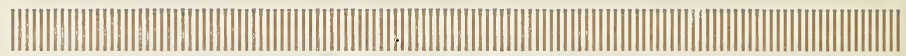

This edition is limited to one-hundred and twenty-five numbered copies of which this copy is number 
Washingtorn Wilatelic tosiety.

Z

7164

THE

STAMP PUBLICATIONS

OF THE

STATE OF COLORADO

BY

CHAS. A. NAST

Reprinted from The Stamp Collector

Price 25 cents

1912

GEORGE W. LINN CO.

Columbus, Ohio

||||||||||||||||||||||||||||||||||||||||||||||||||||||||||||||||||||||||||||||||||||||||||||||||||||||||||||||||||||||||||||||||| 



\section{The Stamp Publications of the State of Colorado}

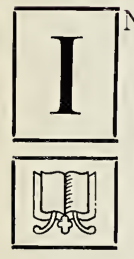

N PREPARING this short sketch of the history of philatelic literature in Colorado, I have tried to make the list complete and I am quite sure of all the facts and figures here given. With the single exception of the "Cyclone," which is credited with three issues in this state, I have seen and read every paper listed herein. I begin with those published in Denver, and keep that city's papers separate from those in other parts of the state because that city has always been the scene of great philatelic endeavor. In the past Denver has entertained every one of the great philatelic societies in annual convention, and for its size has done much for plibately. Never once without its local organization, it has in addition generally been represented by a stamp paper of some kind. At one time in its past history no less than three papers were published contemporaneously in Denver. That was in 188\%, and they were all good; a great record truly. In fact Denver was a greater stamp center in 1888 than it is today, though its population is four times as large. At this writing we can boast of a fine local society, and in point of enthusiasm few can beat it. 


\section{Magazines Published in Denver}

\section{○}

\section{THE STAMP}

This was the first paper published within the domain of the state. Its first number appeared in March, 1856, size 6x9. Edited and published by. D. W. Osgood and John E. Feldwisch. The first of these is living in Seattle, Wash., and the last died in August, 1910. Both these gentlemen were able and experienced newspaper men, and the paper soon ranked as one of the most popular stamp journals of its day. A series of portraits (wood engravings) of philatelists prominent ir those days graced its pages, one of these being $A$. W. Dunning, who is still actively interested.

\section{COLLECTOR'S REVIEW}

First appeared in October, 1886, about the same size as the foregoing, 6x8 $1 / 2$. Published by Henry A. Babb and Frank E. Carstarphen. It was an able and honorable competitor, and appeared regularly for seventeen months. Both proprietors gave it up to go into professions, Carstarphen moving to New York City where he soon became a prominent theatrical attorney. Its most notable contributor was Major (then Lieut.) J. M. Partello, whose series of articles entitled "A Philatelist's Observations Abroad" were very in. teresting and make good reading even today.

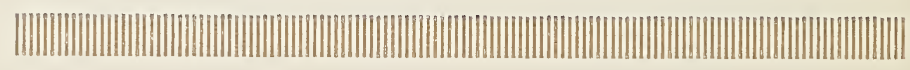




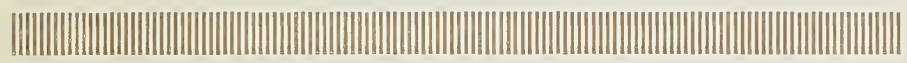

\section{STAMP RECORD}

During the year 1857 a new monthly journal was launched by Messrs. Tedford and Richards. It was very well edited and printed. Only four numbers appeared, viz.: February, March, April and May. Evidently Denver was not the best field for a third stamp paper. This was also a $6 \times$ ? of four and eight pages. It is very scarce as the edition was undoubtedly small.

\section{COLLECTOR'S COMMENT}

Also a monthly, size $6 \times 81 / 2$, consisting of four pages. First number appeared in October, 1sss. After the second number it was sold to the Colorado Philatelic Co. by its owner and publisher, Harry Babb. Only three numbers were ever issued. Of all Colorado's publications it was the least important, and yet among the advertisers I note, Batchelder Stamp Co., of St. Louis; W. H. Greany, San Francisco; Townsend, of Akron, Ohio; H. C. Beardsley, F. N. Massoth and other well known names.

\section{COLLECTOR'S REVIEW}

On April 1st, 1893, E. W. Plummer resurrected this old name. Eddie was only 16 years old then, but he certainly produced a fine readable journal for those days. The size was 6x9 for the first three numbers, while the fourth and last number, issued from Berkeley, a suburb and part of Denver, was $8 \times 101 / 2$ inches. Four pages to each number. How much better if all had been of like dimensions? How-

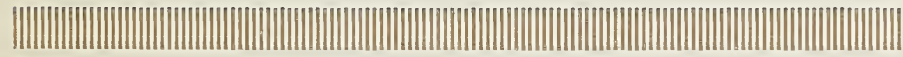




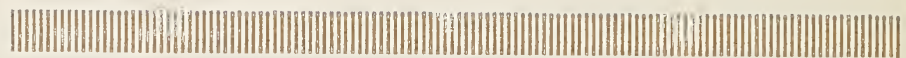

ever, Plummer was not to be without competition, and while Denver had been without any stamp paper for five years it was now to have two almost simultaneously.

\section{THE PHILATELIST}

On April 10th, 1893, Lewis Bishop issued the first number of what all regarded at the time, as the best monthly in the United States. Like its twin brother, the "Collector's Review," it ceased after its fourth number, the last issue being a double number for July-August. This magazine contained 22 to 26 pages besides cover. It is not rare, a big edition having been printed each month. Such men as Louis G. Quackenbush, Chas. E. Severn, J. P. Glass, Charles E. Jenny, and that young giant intellect W. A. Withrow, H. C. Beardsley and others were regular contributors. No one has so completely dropped out of existence as its publisher and editor, Lewis Bishop. A great many people thought at the time of the of the South American swindle that "Williams \& Co." must be this same Bishop. He left Denver under a cloud and his competitor, Plummer, had the satisfaction of giving in his last number of the "Review" a full description of the thrilling escape of this defaulter, while under arrest on the charge of fraud through the mails. He had been taken into custody by a post office inspector, and while the officer's attention was distracted for a moment, he jumped out of a second story window and alighted on a skylight through which he crashed unhurt, and before the astonished clerks cculd recover from their surprise, had rushed out of the store, into the street, and was never seen again. No doubt the panic of 1893 laid low both of these publications. 


\section{ROCKY MOUNTAIN STAMP}

In 1895 things began to look up in Denver and in January of this year the first number of this well known and deservedly popular paper appeared. The editor was Jos. S. Davis and the business manager C. C. Harrington. After a few issues the editorial management was taken up by John E. Zahn, who continued to look after all except the last two numbers, which were edited and published by J. F. Dodge, of New Oxford, Pa. By a strange coincidence exactly $3 \mathrm{~s}$ numbers were published (though not consecutively), the identical number of issues of the "Stamp." Denver's first journal devoted to philately. Its last issue bears date of November, 1 s9s.

\section{THE CURIO}

In February, 1895, a magazine bearing this name ap peared, size $5 \frac{1}{2} 2 \times 81 / 2$ inches, 8 pp. and cover, pulblished by Edward Plummer and edited by himself and Oney Carstarphen. It was devoted to natural science, but had a good stamp department, several well written articles on stamps being the best part of the journal. Only one number was ever issued.

\section{JUVENILE PHILATELIST}

After an interval of eight years following the demise of the "Rocky Mountain Stamp," the silence was broken by the appearance of two small papers, projected by young collector-dealers. In February, 1906, Mr. Arnold L. Neil issued the first number of the "Juvenile Philatelist," size $6 \times 9$, con-

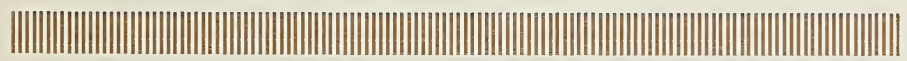




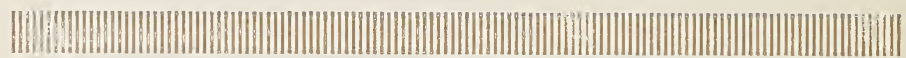

sisting of six pages, which were increased to eight with No. 2. Only four numbers were issued, viz.: February, March, April and May. It was good for a juvenile paper.

\section{WESTERN STAMP COLLECTOR}

They always do things in pairs in Denver apparently. In April, 1906, Mr. C. M. Snyder issued the first number of his publication. Like all the others this too was a monthly. Only three numbers were issued. The last contained an article written for boys on the easiest way to obtain match and medicine stamps.

\section{STAMP JOURNAL}

This was first issued in January, 1908, with Dr. H. A Davis as business manager and Charles A. Nast editor, these gentlemen being elected to their respective offices by the directors of the publishing company, composed of eight members of the Denver Stamp Club. Owing to change of employment of the business manager which necessitated his traveling all over the state, the paper was sold in February. 1909, to Clarence P. DeKay, who became sole proprietor. After issuing the paper regularly each month thereafter Mr. DeKay moved the paper to Florida, N. Y., from whence in September, 1909 , the first edition was printed. It is still current. In October, 1910, Mr. Nast relinquished the editorial chair to Mr. DeKay who now assumes full authority. From a small beginning this journal has grown to a very large and influential one. It is Colorado's best offering to stamp literature. Much of its success is due to the extraordinary busi-

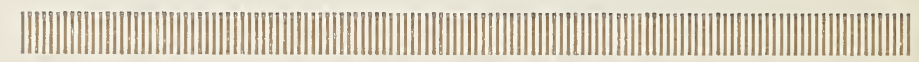


ness ability of its proprietor. The reason for giving only 11 numbers to $\mathrm{Vol}$. I of this paper is due to a double number (9-10) in October, 190s. The size is $6 \times$ ? and latterly has consisted of 36 to 52 pages.

\section{VEST POCKET PHILATELIST}

This diminutive stamp paper first made its appearance in December, 190s. It is still current, and though small in size, $23 / 4 \times 31 / 2$ inches, it is well filled with first-class stamp literature, contains from 12 to $16 \mathrm{pp}$., and is edited and publisted by Dr. H. A. Davis, 2124 East 12th Ave., Denver, Colo. The first four numbers of Vol. I appeared in December, 1908, January, February and March, 1909, then there was a break, No. 5 appearing in the following September and No. 6 in December, 1909. Since then it has been regularly issued each month. It is the little "Puck" of stampdom.

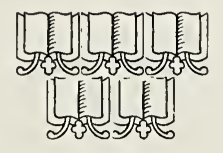





\section{Magazines Published Outside of Denver}

\section{○}

\section{ROCKY MOUNTAIN PHILATELIST}

Published at Boulder, Colo., by H. E. Roth and E. D. Torrey. Only two numbers dated February and June $1 n$ 1593. Size $6 \times 81 / 2$. No. 1 had $12 \mathrm{pp}$. and cover, and was very promising. No. 2 dropped down to $S$ pp. and cover and from the contents it was easy to see that the end had been reached. They, however, make a very interesting addition to any stamp library. The initial number contains a well written article by Roy F. Green on "Women's Part in Philately," and the speech delivered by Senator E. O. Walcott in the U. S. Senate denouncing the Post Office Department for foisting the Columbian emission of stamps on collectors, comparing our government to South American republics which printed stamps just to sell to stamp collectors. He referred to them as "porous plasters."

\section{THE STAMPMAN}

Publislied first at Pueblo, Colo, in a $6 \times 9$ size by D. W. Osgood, a well known dealer, in 1896. Its first number appeared in December, and the other numbers of Vol. I are credited to January, 1897, February, March, May and JulyAugust. Each consists of four pages of well written articles. With Vol. II there was a change in size to $33 / 4 \times 65 / 4$ inches, of $8 \mathrm{pp}$. Vol. III had four numbers of $10 \mathrm{pp}$. each. 
$\mid$

With Vol. IV came another departure in size. It now had four pages of a size $6 \mathrm{~T} / 2 \times 93 / 4$ inches, oblong shape, and in Vol. VI another change to $5 \mathrm{t} / 2 \times 10$ inches. The last four numbers of this Journal are dated as follows: No. 1, Pueblo, June, 1901; No. 2, South Fork, Colo., February, 1902; No. 3. South Fork, June, 1902; No. 4, South Fork, October, 1902. It should be noted that Mr. Osgood issued these as house organs and trade sheets and therefore he gave little heed to the needs of philatelic literature collectors, but this is all the more to be deplored, because he was an able editor and his work was in a humorous vein, and a style all his own. I consider a file of the "Stampman" as one of the best things in my library. I still lack three numbers of completeness.

\section{PHILATELIST'S BEACON}

Only one number was ever issued and only one copy is known to date. It appeared at Golden, Colo., in January, 1902 , and was published by Chester Ehle. It consisted of 12 pp., size $5 \times 6$ inches, and cover, the last being lavender colored and printed in red and green ink. I received a copy from Mr. Ehle himself after collectors on both sides of the water had advertised in vain for a copy. About this time I was induced to nart with it to a collector who wanted it very much and who has done much for philately the world over. I therefore was very pleased to send it to England, where it now graces the library of the Earl of Crawford.

\section{THE CYCLONE}

Up in Wisconsin in a little town called Hika this paper first saw the light of day. I do not know much about this

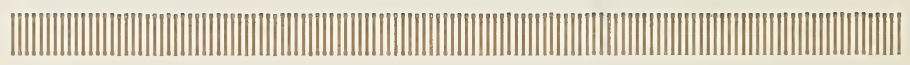


one, and I am indebted to Messrs. Ricketts and Cook for my information. Vol. II, Nos. 9-10 for (September-October, 1902.) was printed in Golden, Colo., by Chester Elile, editor, while Fred Billings of Marshalltown, Iowa, was the business manager. Nobody knows about Nos, 11 and 12, but there are several copies extant of Vol. III, No. 1, March, 1903, which was also printed at Golden, so it is fair to assume that these were also published there. The last number of this Journal was Vol. III, No. 2, published at Ozark, Mo., dated April, 1903. As a stamp paper it was very fair and well worth preserving.

\section{LITTLE GEM}

A college paper published at Loveland, Colo. Originally it had no stamp department, this being furnished by A. H. Hoffman of Denver. Mr. Hoffman contributed his notes occasionally, and they appeared in 14 different numbers of the paper during 1906. The paper has discontinued.

\section{THE WESTERN COLLECTOR}

And now we close with the last venture. This is a publication which looks well and bids fair to live a long and useful life. It is printed and published by Claude G. Beals of Boulder, Colo. He is an expert printer, hence the typograplic appearance is neat and tasty. Originally printed under the name of "Union Souvenir Card Exchange" and containing only lists of card collectors with No. 4 (August-September, 1910,) the change of name was made and from an $\mathrm{S}$ pp. list it blossomed into a readable stamp journal

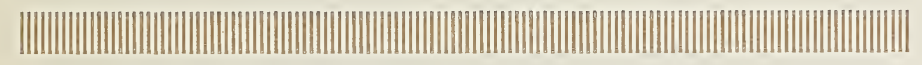


of 12 pp. and cover. All numbers are size $5 \frac{1}{2} \times 8 \frac{1}{2}$. The initial number bears date, May, 1910 , and No. 7 is dated December, 1910.

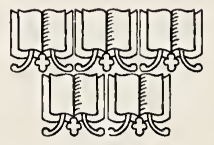




\section{Pamphlets, Etc.}

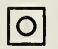

In addition to the above we may add two interesting items. No hand books were ever issued so far as we know, but we note the following:

\section{COLORADO STATE ADDRESS BOOK}

Size $4 \frac{1}{8} \times 53 / 8,20$ pp. and cover, edited by Oney K Carstarphen, published by Beardsley of St. Joseph, Mo., and O. K. Carstarphen of Denver. It contains a philatelic history of Colorado to date of issue, 1897. Besides many portraits of collectors it includes a list of all collectors living in Colorado.

\section{SOUVENIR PROGRAM}

Size $8 \times 11$ inches, 8 pages. Issued by Colorado Branch, No. 22, on the occasion of the 22nd annual convention of the Am. Phil. Association at Denver, Colo., 190\%. It contains a splendid lot of cuts of collectors and groups, besides interesting reading matter. 



\section{Check List}

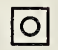

The Stamp-Denver, Colo., 18s6-Vol. I, 12 nos.; II, 12 nos.; III, 12 nos.; IV, 1, 2.*

Collectors Review-Denver, Colo., 1857-Vol.I, 12 nos.; II. $1,2,3,4,5 . *$

Stamp Record-Denver, Colo., 18s7-Vol. I, 1, 2, 3, 4, ;.* Collectors Comment-Denver, Colo., 18ss-Vol. I, 1, 2, 3.*

Collectors Review-Denver, Colo., 1893-Vol. I, 1, 2, 3, 4.*

The Philatelist-Denver, Colo., 1893-Vol. I, 12 nos.; II, 1: nos.; III, 12 nos.; IV, 1, 2.*

Rocky Mountain Stamp-Denver, Colo., 189.5-Vol. I, 12 nos.; II, 12 nos.; III, 12 nos.; IV, 1, 2.*

The Curio-Denver, Colo., 1895-Vol. I, 1.*

Jivenile Philatelist-Denver, Colo., 1906-Vol. I, 1, 2, 3, 4.* Western Stamp Ccllector-Denver, Colo., 1906-Vol I, 1, 2. $3 . *$

Stamp Journal-Denver, Colo., and Florida, N. Y., 1908-Vol. I, 11 nos.; II, 12 nos.; III 12 nos. current.

Vest Pocket Philatelist-Denver, Colo., 190s-Vol. I, 6 nos.; II, 6 nos.; IlI, 6 nos.; current.

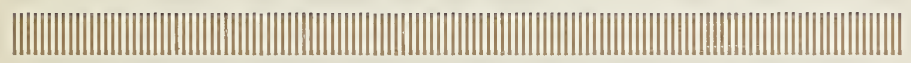


Rocky Mountain Philatelist-Boulder, Colo,, 1593-Vol. I, $1,2 . *$

The Stampman-Pueblo and South Fork, Colo., 1896-Vol. I, 6 nos.; II, 6 nos.; III, 4 nos.; IV, 6 nos.; V, 6 nos.; VI, 1, 2, 3, 4.*

Philatelist's Beacon-Golden, Colo., 1902-Vol. I, 1.* (Jan., 1902.)

The Cyclone-Hika, Wis. and Golden, Colo., 1902-Vol I, 12 nos.; II, 11 nos.; III, 1, 2.*

Little Gem-Loveland, Colo., 1906-14 nos, variously dated. Stamp department only.

Western Collector-Boulder, Colo., 1910-Vol. I, 1, 2, 3, 4, 5, 6, 7. Current.

*Last number.

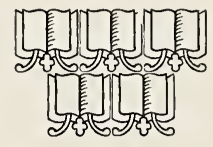


. 

SMITHSONIAN INSTITUTION LIBRARIES 